Volume 3, Nomor 2, Desember 2020

\title{
SISTEM PREDIKSI KONDISI KELAHIRAN BAYI MENGGUNAKAN KLASIFIKASI NAÏVE BAYES
}

\author{
Handini Arga Damar Rani ${ }^{1}$, Syaifuddin Zuhri ${ }^{2}$ \\ Universitas IVET ${ }^{1,2}$ \\ *hani.arga@gmail.com
}

Diterima: November 2020. Disetujui: Desember 2020. Dipublikasikan: Desember 2020

\begin{abstract}
ABSTRAK
Dalam bidang kesehatan, data mining dapat dimanfaatkan untuk memprediksi suatu penyakit dari data rekam medis pasien. Dengan metode research and development klasifikasi pada data mining, data seperti umur, tekanan darah, berat badan, letak janin, tinggi fundus uterus dan atribut lainnya, dapat digunakan untuk memprediksi kemungkinan pasien terkena suatu penyakit. Oleh karena itu, peneliti membuat sistem prediksi kondisi kelahiran bayi mengunakan metode klasifikasi naïve bayes yang berfungsi untuk memprediksi kelahiran bayi. Teknik data mining yang diterapkan pada aplikasi yang dibangun adalah metode klasifikasi naïve bayes. Dengan menggunakan pengembangan sistem berbasis web yaitu akuisisi pengetahuan. Hasil dari penelitian ini adalah aplikasi untuk memprediksi seseorang akan melahirkan secara normal atau beresiko(cesar) berdasarkan hasil pemeriksaan dokter. Dari hasil prediksi tersebut dapat digunakan untuk menentukan hasil rata-rata kelahiran bayi setiap bulan. Data yang kami gunakan ada total 165 data ibu hamil diantaranya kami bagi 2 yaitu 110 data training dan 55 data testing/data uji, model prediksi dievaluasi menggunakan fold cross validation dalam proses evaluasi dan perhitungan nilai akurasi, precission, dan recall. Dengan nilai akurasi $92,73 \%$ dan precission $83,33 \%$ serta recall $100 \%$.
\end{abstract}

Kata kunci: Data Mining, Prediksi Kelahiran, Klasifikasi, Nä̈ve Bayes.

\begin{abstract}
In the health sector, data mining can be used to predict a disease from patient medical records. With the research and development method of classification in data mining, data such as age, blood pressure, body weight, fetal location, uterine fundal height and other attributes can be used to predict the possibility of a patient getting a disease. Therefore, researchers created a prediction system for the condition of the baby's birth using the naïve Bayes classification method which serves to predict the birth of a baby. Data mining techniques that are applied to applications that are built is the naïve Bayes classification method. By using a web-based system development, namely knowledge acquisition. The results of this study are applications to predict someone will give birth normally or at risk (cesarean) based on the results of a doctor's examination. From the prediction results, it can be used to determine the average result of the birth of a baby every month. The data we use is a total of 165 data for pregnant women, including us for 2, namely 110 training data and 55 testing data, the prediction model is evaluated using fold cross validation in the evaluation process and calculating the value of accuracy, precission, and recall. With an accuracy value of $92,73 \%$ and $83,33 \%$ precission and $100 \%$ recall.
\end{abstract}

Kata kunci: Data Mining, Birth Prediction, Classification, Nä̈ve Bayes. 


\section{PENDAHULUAN}

Data mining adalah proses yang menggunakan teknik statistik, matematika, kecerdasan buatan, dan machine learning untuk mengekstraksi dan mengidentifikasi informasi yang bermanfaat dan pengetahuan yang terkait dari berbagai database besar [1]

Data mining terutama digunakan untuk mencari pengetahuan yang terdapat dalam basisdata yang besar sehingga sering disebut Knowledge Discovery in Databases (KDD). Proses pencarian pengetahuan ini menggunakan berbagai teknik-teknik pembelajaran komputer (machine learning) untuk menganalisis dan mengekstraksikannya [2]. Proses pencarian bersifat iteratif dan interaktif untuk menemukan pola atau model yang sahih, baru, bermanfaat, dan dimengerti. Dalam penerapannya data mining memerlukan berbagai perangkat lunak analisis data untuk menemukan pola dan relasi data agar dapat digunakan untuk membuat prediksi [3].

Setiap orangtua pasti berusaha yang terbaik untuk persalinan akan berjalan lancar dan dapat melahirkan bayi dengan sempurna. Dimana Prediksi kehamilan berisiko merupakan suatu keadaan dimana kehamilan dapat berdampak buruk pada keselamatan ibu dan bayinya. Kehamilan berisiko dapat diprediksi sejak masa kehamilan dini melalui banyak faktor di antaranya kondisi fisik dan mental ibu hamil, asupan nutrisi, dan penyakit bawaan. Ibu hamil yang masuk ke dalam golongan hamil dengan resiko perlu meningkatkan kewaspadaan sejak dini dan merencanakan tindakan persalinan. karena banyak ibu hamil tidak menyadari resiko yang ditanggung dari kondisi kehamilannya sejak dini [4].

Berdasarkan survei Demografi dan Kesehatan Indonesia (SDKI) tahun 2012, angka kematian ibu di Indonesia terbilang masih tinggi, yaitu 359 per 100.000 kelahiran hidup, sedangkan target global MDGs (Millenium Development Golas) kelima yaitu menurunkan Angka Kematian Ibu (AKI) menjadi 102 per 100.000 kelahiran hidup [5].

Prediksi terhadap kehamilan beresiko bisa dilihat dari data rekam medis pasien, maka dari itu penulis berkeinginan untuk membuat sistem prediksi kondisi kelahiran bayi secara mandiri melalui sebuah sistem aplikasi. Informasi yang didapat dari sistem aplikasi tersebut didasarkan pada ilmu kebidanan.

Beberapa penelitian yang relevan dengan penelitian ini, di antaranya penelitian yang dilakukan oleh Hasni GA dan Tedy Setiadi tahun 2014 tentang "Penerapan data mining untuk mengetahui factor-faktor yang mempengaruhi kelahiran bayi menggunakan association rules". Penelitian ini akan menghasilkan sebuah aplikasi untuk menampilkan informasi dari proses data mining yaitu faktor yang mempengaruhi kelahiran bayi khususnya faktor dalam data rekam medis kelahiran bayi. Informasi yang akan ditampilkan berupa nilai support dan confidence. Semakin tinggi nilai support dan confidence maka semakin kuat nilai hubungan antar item. Hasil dari proses data mining ini dapat digunakan sebagai rekomendasi kebijakan baru bagi BKKBN untuk menekan angka kelahiran bayi yang tinggi. Hasil penelitian ini adalah Nilai support 46,14\% dan nilai confidence 94,4\% aturan asosiasi yang dihasilkan jika jumlah anak 1 maka usia ibu antara 20 - 30 yan g artinya faktor yang mempengaruhi kelahiran bayi yaitu jumlah anak 1 mempunyai kemungkinan 94,4\% juga dapat berpengaruh untuk faktor usia ibu antara 20 - 30 terhadap kelahiran bayi. Aturan ini mewakili 46,14\% dari database [7].

Selanjutnya adalah penelitian yang dilakukan oleh Ari Muzakir dan Rika Anisa tahun 2016 yang berjudul "Model data mining sebagai prediksi penyakit hipertensi kehamilan dengan teknik decision tree" hasil penelitian ini adalah decision tree dan rules 
yang dapat memprediksi penyakit hipertensi dalam kehamilan, dilakukan evaluasi dengan supplied test set menggunakan WEKA dihasilkan kesalahan (error) $7.3427 \%$ dan tingkat akurasi $92.6573 \%$. Data training yang berjumlah 286 instances, hal ini menunjukkan bahwa terdapat 265 instances yang akurat dan 21 instances yang error atau prediksinya salah [8].

Penelitian yang dilakukan oleh Hilda Amalia dan Evicienna tahun 2017 dengan judul "Komparasi metode data mining untuk penentuan proses persalinan ibu melahirkan" [9] dengan membandingkan beberapa metode klasifikasi yaitu metode naïve bayes, C4.5, dan Neural Network hasil penelitian ini menunjukkan bahwa metode dengan nilai akurasi tertinggi naive bayes yaitu $94 \%$ dan nilai AUC tertinggi juga yaitu 0.971. Performace AUC dikelompokan kedalam lima kelompok yaitu: 0.90-1.00 disebut Klasifikasi yang sangat baik; 0.80-0.90 disebut Klasifikasi Bagus; 0.70-0.80 disebut Klasifikasi Lepas; $0.60-0.70$ disebut Klasifikasi Miskin [10]. Dalam penelitian untuk nilai AUC naive bayes dan neural network masuk ke dalam kategori sangat baik, sementara algoritma C4.5 termasuk kedalam kategori bagus.

Dalam penelitian yang telah dilakukan sebelumnya oleh Naisha dengan judul "Aplikasi Prediksi Usia Kelahiran Bayi Dengan Metode Naïve Bayes" pada Tahun 2018, telah didapatkan nilai accuracy tertinggi $78.69 \%$, nilai precision tertinggi $70.14 \%$ dan nilai recall tertinggi $63.64 \%$ [11]. Pada kasus penentuan usia kelahiran dengan algoritma Naïve Bayes diperoleh nilai precision, recall dan accuracy yang lebih tinggi dibandingkan penentuan usia kelahiran dengan algoritma C.45 [12].

Selain itu pada penelitian Desy Kartika I. dengan judul "Aplikasi Prediksi Usia Kelahiran Dengan Metode K-Nearest Neighbor" pada tahun 2019, dengan menggunakan metode K-Nearest Neighbor (pendekatan tetangga). Variable yang digunakan merupakan bagian dari faktor penting yang dialami seorang ibu pada saat proses kehamilan, diantaranya: usia ibu hamil, tekanan darah, jumlah bayi, riwayat persalinan, riwayat abortus/kuretase, malnutrisi, penyakit bawaan sebelum hamil dan masalah saat kehamilan. Hasil dari penelitian ini berupa aplikasi prediksi usia kelahiran dengan nilai precicion tertinggi 100 $\%$, nilai recall tertinggi $84.905660377358 \%$ [13].

Selain itu ada pula penelitian yang dilakukan Jefi dengan judul "Prediksi Bayi Lahir Secara Prematur Dengan Menggunakan Metode C.45 Berbasis Particle Swarm Optimization Pada Klinik Umi”, pada tahun 2019, dengan model algoritma C4.5 dan model algoritma $\mathrm{C} 4.5$ berbasis particle swarm optimization untuk mendapatkan rule dalam memprediksi kelahiran bayi secara prematur dan memberikan nilai akurasi yang lebih akurat. Setelah dilakukan pengujian dengan dua model yaitu Algoritma C4.5 dan Algoritma C4.5 berbasis particle swarm optimization maka hasil yang didapat adalah Algoritma C4.5 menghasilkan nilai akurasi sebesar 94,30\% dan nilai AUC sebesar 0,986 dengan tingkat diagnosa Excellent Classification, namun setelah dilakukan penambahan yaitu Algoritma $\mathrm{C} 4.5$ berbasis particle swarm optimization nilai akurasi sebesar 97,91\% dan nilai AUC sebesar 0,997 dengan tingkat diagnosa Excellent Classification. Sehingga kedua metode tersebut memiliki perbedaan tingkar akurasi yaitu sebesar $3.61 \%$ [14]

\section{METODE PENELITIAN}

Pada bab ini akan diberikan beberapa penjelasan mengenai metode penelitian yang akan digunakan dalam penelitian ini yaitu dengan model Research and development. Penelitian ini dilakukan dengan langkah sebagai berikut: 


\section{Rancangan Penelitian}

Metode yang diusulkan pada penelitian ini yaitu menggunakan metode research and development, Langkah-langkah tersebut disusun sedemikian rupa, dan penggambarannya ditunjukkan pada gambar 1 berikut:

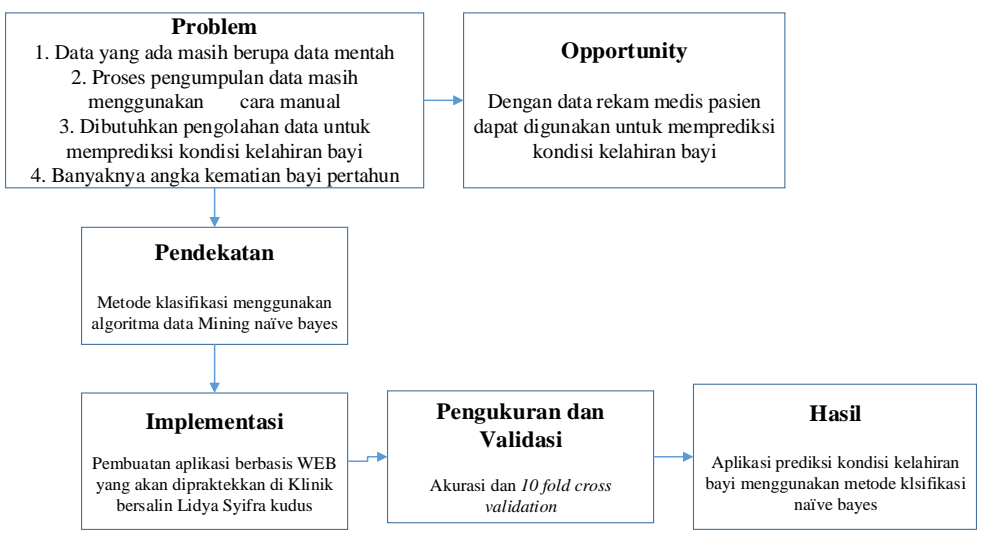

Gambar 1. Kerangka Pemikiran

Dalam proses penelitian berdasarkan flowchart di bawah ini:

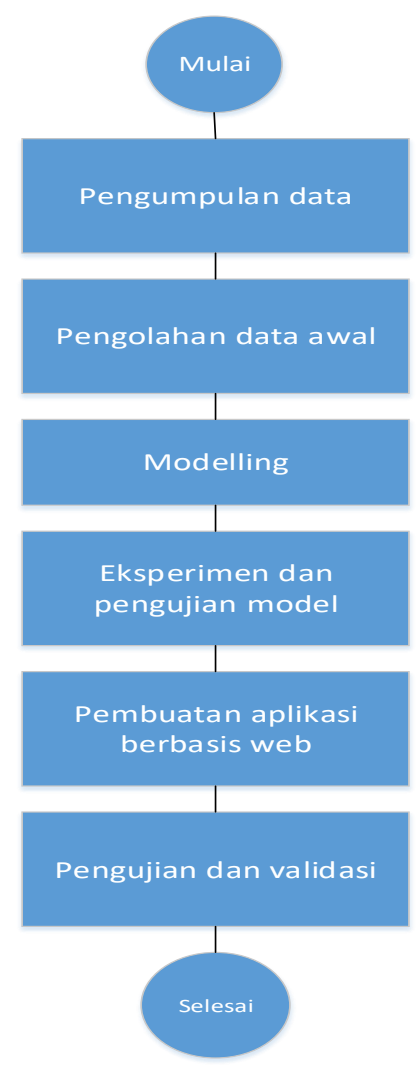

Gambar 2. Alur Penelitian

\section{Pengumpulan data}

Pada penelitian ini teknik pengumpulan data yang kami gunakan adalah dengan observasi dan wawancara pada sebuah klinik bersalin di kota Kudus, dari hasil observasi dan wawancara kami peroleh data berupa Data catatan ibu hamil total 165 data ibu hamil diantaranya kami bagi 2 yaitu 110 data training dan 55 data testing/data uji. Data tersebut adalah data pasien hamil selama 6 bulan. Kemudian data tersebut kami masukkan dalam format excel. Data yang ada pada database sering kali tidak semuanya atribut data dipakai, oleh karena itu hanya atribut data yang sesuai untuk dianalisis yang akan diambil dari database kemudian diklasifikasi dengan metode naïve bayes.

\section{Analisis Data}

Data yang kita gunakan nantinya akan dibagi menjadi 2 bagian yaitu:

- Data training untuk pembentukan model, dan data testing digunakan untuk pengujian model

- Data validation untuk memvalidasi model kita valid atau tidak

\section{Pengolahan Data Awal}

a. Pembersihan data (data cleaning)

Pembersihan atribut data set catatan ibu hamil merupakan proses menghilangkan noise dan data yang tidak konsisten atau data tidak relevan. Data-data yang tidak relevan itu juga lebih baik dibuang

\section{b. Integrasi data (data integration)}

Integrasi data merupakan penggabungan data dari berbagai database ke dalam satu database baru. Integrasi data dilakukan pada atribut-aribut yang mengidentifikasikan entitas-entitas yang unik seperti atribut nama, usia, tekanan darah, TFU, letak janin.

\section{c. Seleksi Data (Data Selection)}

Data yang ada pada database sering kali tidak semuanya dipakai, oleh karena itu hanya data 
yang sesuai untuk dianalisis yang akan diambil dari database. Data yang kami gunakan ada total 165 data ibu hamil diantaranya kami bagi 2 yaitu 110 data training dan 55 data testing/data uji. Berikut contoh data yang telah diproses pada tahapan 1-3:

\begin{tabular}{|l|l|l|l|l|l|l|}
\hline Nama & Alamat & TD & BB & Usia & Letak Janin & TFU \\
\hline istiqomah & Sambung & 100 & 49 & 23 & Sesuai & Sesuai \\
\hline Sunarni & Ketanjung & 100 & 52 & 20 & Sesuai & Sesuai \\
\hline Diah & Cangkring & 120 & 55 & 25 & Sesuai & Sesuai \\
\hline Kusriah & Undaan Kidul & 110 & 48 & 24 & Sesuai & Tidak sesuai \\
\hline Zuhroh & Ketanjung & 130 & 53 & 27 & Tidak sesuai & Tidak sesuai \\
\hline Anifa & Ngemplik & 120 & 46 & 26 & Sesuai & Sesuai \\
\hline Sumini & Ngemplik & 110 & 47 & 19 & Tidak sesuai & Tidak sesuai \\
\hline Ngatemi & Ketanjung & 100 & 56 & 20 & Tidak sesuai & Sesuai \\
\hline Muzarofah & Ngemplik & 100 & 54 & 29 & Sesuai & Sesuai \\
\hline
\end{tabular}

Gambar 3. Contoh hasil seleksi data

\section{Modeling}

Desain model sistem untuk memprediksi adalah sebagai berikut:

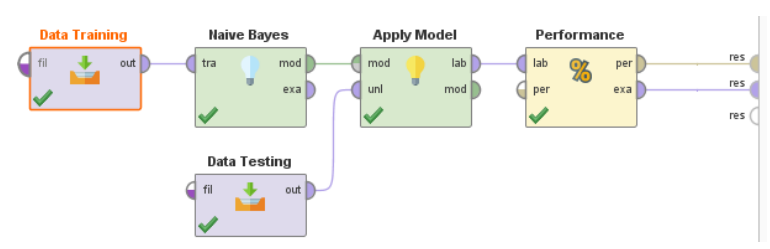

Gambar 4. Model analisis data menggunakan rapid miner

\section{Eksperimen dan Pengujian}

Pengujian ini betujuan untuk mengetahui hasil kerja klasifikasi naïve bayes dalam mengklasifikasikan data ke dalam kelas normal dan kelas beresiko. Pada uji coba in diberikan data latih untuk membentuk tabel probabilitas. Langkah selanjutnya akan diberikan data uji untuk menguji tabel probabilitas yang sudah terbentuk.

\section{a.Pengujian ke-1}

Menggunakan data training pasien sebanyak 50 , berikut hasil perhitungan dari 50 data training

$$
\begin{aligned}
& \mathrm{P}(\text { Normal })=30 / 50=0,6 \\
& \mathrm{P}(\text { Beresiko })=20 / 50=0,4 \\
& \mathrm{P}(\text { letak janin }=\text { sesuai } \mid \text { normal })=30 / 30=1 \\
& \mathrm{P}(\text { letak janin }=\text { tidak sesuai } \mid \text { beresiko })= \\
& 7 / 20=0,4
\end{aligned}
$$

$$
\begin{aligned}
& \mathrm{P}(\text { TFU }=\text { sesuai } \mid \text { normal })=30 / 30=1 \\
& \mathrm{P}(\mathrm{TFU}=\text { tidak sesuai } \mid \text { beresiko }) \\
& =8 / 20=0,35 \\
& \mathrm{P}(\text { tekanan darah }=\text { normal } \mid \text { normal })= \\
& 30 / 30=1 \\
& \mathrm{P}(\text { tekanan darah }=\text { rendah } \mid \text { beresiko }) \\
& =7 / 20=0,35 \\
& \mathrm{P}(\text { tekanan darah }=\text { tinggi } \mid \text { beresiko }) \\
& =2 / 20=0,1
\end{aligned}
$$

$\mathrm{P}($ Normal) $\mathrm{P}$ (letak janin $=$ sesuai $\mid$ normal) $\mathrm{P}$ $(\mathrm{TFU}=$ sesuai $\mid$ normal) $\mathrm{P}$ (tekanan darah $=$ normal | normal)

$$
\begin{aligned}
& =30 / 50 * 30 / 30 * 30 / 30 * 30 / 30 \\
& =0,6 * 1 * 1 * 1 \\
& =0,6
\end{aligned}
$$

$\mathrm{P}$ (Beresiko) $\mathrm{P}$ (letak janin = tidak sesuai beresiko) $\mathrm{P}(\mathrm{TFU}=$ tidak sesuai $\mid$ beresiko) $\mathrm{P}$ (tekanan darah $=$ rendah $\mid$ beresiko) $\mathrm{P}$ (tekanan darah $=$ tinggi $\mid$ beresiko)

$$
\begin{aligned}
& =02 / 50 * 7 / 20 * 8 / 20 * 7 / 02 * 2 / 20 \\
& =0,4 * 0,35 * 0,4 * 0,35 * 0,1 \\
& =0,196
\end{aligned}
$$

Dari hasil perhitungan dengan menggunakan 50 data training pasien, kita simpulkan bahwa nilai probabilitas tertinggi ada pada (P|Normal) jadi, status kelahiran masuk dalam kelompok normal, hal ini didapat karena hasil perhitungan nilai normal lebih besar dari nilai resiko.

\section{b.Pengujian ke-2}

Menggunakan data training pasien sebanyak 100 , berikut hasil perhitungan dari 100 data training

$$
\begin{aligned}
& \mathrm{P}(\text { Normal })=58 / 100=0,58 \\
& \mathrm{P}(\text { Beresiko })=42 / 100=0,42 \\
& \mathrm{P}(\text { letak janin }=\text { sesuai } \mid \text { normal })=58 / 58=1 \\
& \mathrm{P}(\text { letak janin }=\text { tidak sesuai } \mid \text { beresiko })= \\
& 20 / 42=0,476 \\
& \mathrm{P}(\mathrm{TFU}=\text { sesuai } \mid \text { normal })=58 / 58=1 \\
& \mathrm{P}(\mathrm{TFU}=\text { tidak sesuai } \mid \text { beresiko }) \\
& =17 / 42=0,405 \\
& \mathrm{P}(\text { tekanan darah }=\text { normal } \mid \text { normal }) \\
& =58 / 58=1 \\
& \mathrm{P}(\text { tekanan darah }=\text { rendah } \mid \text { beresiko }) \\
& =12 / 42=0,286 \\
& \mathrm{P}(\text { tekanan darah }=\text { tinggi } \mid \text { beresiko }) \\
& =2 / 42=0,048 \\
& \mathrm{P}(\text { Normal }) \mathrm{P}(\text { letak janin }=\text { sesuai } \mid \text { normal }) \mathrm{P} \\
& (\text { TFU }=\text { sesuai } \mid \text { normal }) \mathrm{P}(\text { tekanan darah }= \\
& \text { normal } \mid \text { normal }) \\
& \quad=58 / 100 * 58 / 58 * 58 / 58 * 58 / 58
\end{aligned}
$$
normal | normal) 


$$
=0,58 * 1 * 1 * 1
$$$$
=0,58
$$

$\mathrm{P}$ (Beresiko) $\mathrm{P}$ (letak janin = tidak sesuai beresiko) $\mathrm{P}$ (TFU = tidak sesuai $\mid$ beresiko) $\mathrm{P}$ (tekanan darah $=$ rendah $\mid$ beresiko) $\mathrm{P}$ (tekanan darah $=$ tinggi $\mid$ beresiko)

$$
=42 / 100 * 20 / 42 * 17 / 42 * 12 / 42 * 2 / 42
$$

$=0,42 * 0,476 * 0,405 * 0,286 * 0,048$

$$
=0,001
$$

Dari hasil perhitungan dengan menggunakan 100 data training pasien, kita simpulkan bahwa nilai probabilitas tertinggi ada pada (P|Normal) jadi, status kelahiran masuk dalam kelompok normal, hal ini didapat karena hasil perhitungan nilai normal lebih besar dari nilai resiko.

\section{c.Pengujian ke-3}

Menggunakan data training pasien sebanyak 130, berikut hasil perhitungan dari 130 data training

$$
\begin{aligned}
& \mathrm{P}(\text { Normal })=74 / 130=0,569 \\
& \mathrm{P}(\text { Beresiko })=56 / 130=0,431 \\
& \mathrm{P}(\text { letak janin }=\text { sesuai } \mid \text { normal })=74 / 74=1 \\
& \mathrm{P}(\text { letak janin }=\text { tidak sesuai } \mid \text { beresiko })= \\
& 29 / 56=0,518 \\
& \mathrm{P}(\mathrm{TFU}=\text { sesuai } \mid \text { normal })=74 / 74=1 \\
& \mathrm{P}(\mathrm{TFU}=\text { tidak sesuai } \mid \text { beresiko }) \\
& =24 / 56=0,429 \\
& \mathrm{P}(\text { tekanan darah }=\text { normal } \mid \text { normal })=74 / 74 \\
& =1 \\
& \mathrm{P}(\text { tekanan darah }=\text { rendah } \mid \text { beresiko }) \\
& =14 / 56=0,25 \\
& \mathrm{P}(\text { tekanan darah }=\text { tinggi } \mid \text { beresiko }) \\
& =2 / 56=0,36
\end{aligned}
$$

$\mathrm{P}($ Normal) $\mathrm{P}$ (letak janin $=$ sesuai $\mid$ normal $) \mathrm{P}$ $(\mathrm{TFU}=$ sesuai $\mid$ normal $) \mathrm{P}$ (tekanan darah $=$ normal $\mid$ normal)

$$
\begin{aligned}
& =74 / 130 * 74 / 74 * 74 / 74 * 74 / 74 \\
& =0,569 * 1 * 1 * 1 \\
& =0,569
\end{aligned}
$$

$\mathrm{P}$ (Beresiko) $\mathrm{P}$ (letak janin = tidak sesuai beresiko) $\mathrm{P}$ (TFU = tidak sesuai $\mid$ beresiko) $\mathrm{P}$ (tekanan darah $=$ rendah $\mid$ beresiko) $\mathrm{P}$ (tekanan darah $=$ tinggi $\mid$ beresiko)

$$
\begin{aligned}
& =56 / 130 * 29 / 56 * 24 / 56 * 14 / 56 * 2 / 56 \\
& =0,431 * 0,518 * 0,429 * 0,25 * 0,036 \\
& =0,0009
\end{aligned}
$$

Dari hasil perhitungan dengan menggunakan 130 data training pasien, kita simpulkan bahwa nilai probabilitas tertinggi ada pada (P|Normal) jadi, status kelahiran masuk dalam kelompok normal, hal ini didapat karena hasil perhitungan nilai normal lebih besar dari nilai resiko.

\section{d.Pengujian ke-4}

Menggunakan data training pasien sebanyak 165, berikut hasil perhitungan dari 165 data training

$$
\begin{aligned}
& \mathrm{P}(\text { Normal })=97 / 165=0,588 \\
& \mathrm{P}(\text { Beresiko })=68 / 165=0,412 \\
& \mathrm{P}(\text { letak janin }=\text { sesuai } \mid \text { normal })=97 / 97=1 \\
& \mathrm{P}(\text { letak janin }=\text { tidak sesuai } \mid \text { beresiko })= \\
& 34 / 68=0,5 \\
& \mathrm{P}(\mathrm{TFU}=\text { sesuai } \mid \text { normal })=74 / 74=1 \\
& \mathrm{P}(\mathrm{TFU}=\text { tidak sesuai } \mid \text { beresiko }) \\
& =30 / 68=0,441 \\
& \mathrm{P}(\text { tekanan darah }=\text { normal } \mid \text { normal })=74 / 74 \\
& =1 \\
& \mathrm{P}(\text { tekanan darah }=\text { rendah } \mid \text { beresiko }) \\
& =17 / 68=0,25 \\
& \mathrm{P}(\text { tekanan darah }=\text { tinggi } \mid \text { beresiko }) \\
& =3 / 68=0,044
\end{aligned}
$$

$\mathrm{P}($ Normal) $\mathrm{P}$ (letak janin $=$ sesuai $\mid$ normal $) \mathrm{P}$ $(\mathrm{TFU}=$ sesuai $\mid$ normal) $\mathrm{P}$ (tekanan darah $=$ normal | normal)

$$
\begin{aligned}
& =97 / 165 * 97 / 97 * 97 / 97 * 97 / 97 \\
& =0,588 * 1 * 1 * 1 \\
& =0,588
\end{aligned}
$$

$\mathrm{P}$ (Beresiko) $\mathrm{P}$ (letak janin = tidak sesuai beresiko) $\mathrm{P}$ (TFU = tidak sesuai $\mid$ beresiko) $\mathrm{P}$ (tekanan darah $=$ rendah $\mid$ beresiko) $\mathrm{P}$ (tekanan darah $=$ tinggi $\mid$ beresiko)

$$
\begin{aligned}
& =68 / 165 * 34 / 68 * 30 / 68 * 177 / 68 * 3 / 68 \\
& =0,412 * 0,5 * 0,441 * 0,25 * 0,044 \\
& =0,001
\end{aligned}
$$

Dari hasil perhitungan dengan menggunakan 165 data training pasien, kita simpulkan bahwa nilai probabilitas tertinggi ada pada ( $\mathrm{P} \mid$ Normal) jadi, status kelahiran masuk dalam kelompok normal, hal ini didapat karena hasil perhitungan nilai normal lebih besar dari nilai resiko.

\section{HASIL DAN PEMBAHASAN}

Hasil Penelitian Ini berupa aplikasi web yang kami rancang dan bangun untuk memprediksi kelahiran bayi secara normal atau kah beresiko, berikut tampilan aplikasi web dengan menggunakan bahasa pemrograman PHP dan database MYSQL tersebut: 


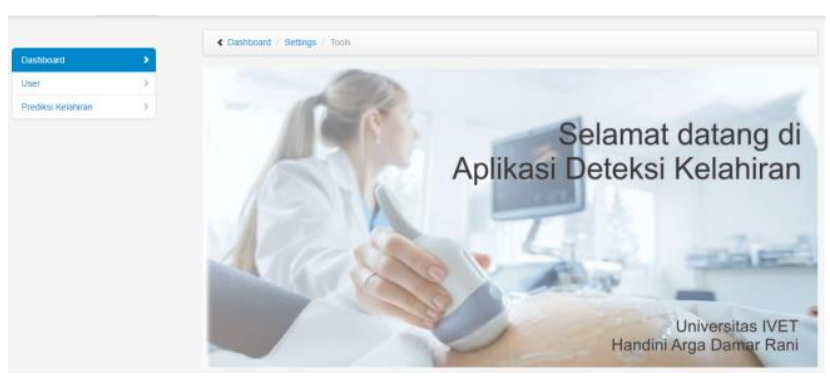

Gambar 5. Tampilan utama Sistem Prediksi Kelahiran bayi

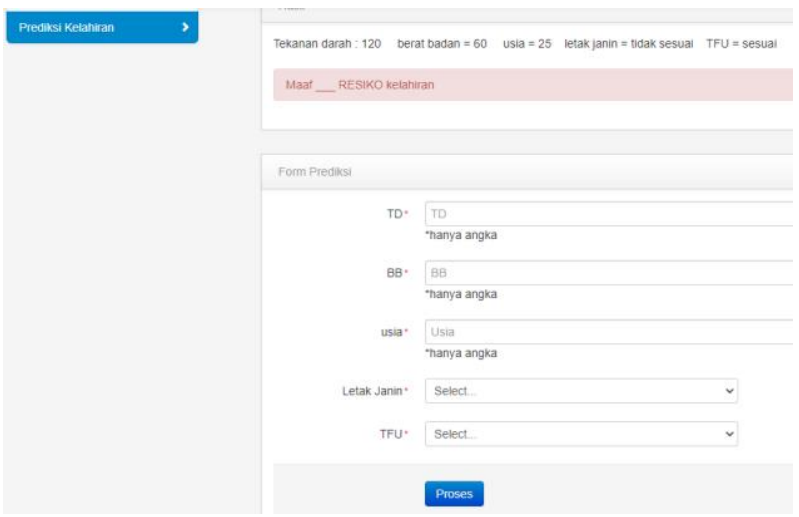

Gambar 6. Tampilan Menu Prediksi kelahiran

Aplikasi web dapat diakses secara online melalui alamat "bidancare.com" dengan login terlebih dahulu.

\section{Pengujian Dan Validasi}

Pengujian kami lakukan dengan perhitungan naïve bayes dan mencari nilai akurasi dari data uji dan training. Setelah itu proses validasi menggunakan X Cross Validation.

Tabel 1. Hasil Akurasi Validasi Menggunakan Cross Validation

\begin{tabular}{l|c|c|c}
\hline & $\begin{array}{l}\text { True } \\
\text { Normal }\end{array}$ & $\begin{array}{l}\text { True } \\
\text { Resiko }\end{array}$ & $\begin{array}{l}\text { Class } \\
\text { Precission }\end{array}$ \\
\hline $\begin{array}{l}\text { Prediksi } \\
\text { Normal }\end{array}$ & $\mathbf{3 1}$ & $\mathbf{0}$ & $\mathbf{1 0 0 \%}$ \\
\hline $\begin{array}{l}\text { Prediksi } \\
\text { Resiko }\end{array}$ & $\mathbf{4}$ & $\mathbf{2 0}$ & $\mathbf{8 3 , 3 3 \%}$ \\
\hline $\begin{array}{l}\text { Class } \\
\text { Recall }\end{array}$ & $\mathbf{8 8 , 5 7 \%}$ & $\mathbf{1 0 0 \%}$ & - \\
\hline
\end{tabular}

Hasil akurasi dalam pengujian ini adalah sebesar 92,73\%. Termasuk dalam kategori yang bagus. Artinya penggunaan metode naïve bayes di anggap tepat dan layak digunakan dalam proses prediksi kelahiran bayi.

\begin{tabular}{l|l|l|l|}
\multicolumn{2}{l}{ precision: $\mathbf{8 3 . 3 3 \%}$ (positive class: Resiko) } \\
& true Normal & true Resiko & class precision \\
\hline pred. Normal & 31 & 0 & $100.00 \%$ \\
\hline pred. Resiko & 4 & 20 & $83.33 \%$ \\
\hline class recall & $88.57 \%$ & $100.00 \%$ & \\
\hline
\end{tabular}

Gambar 7. Nilai class Precision

\begin{tabular}{|l|l|l|l|}
\multicolumn{2}{|c|}{ recall: 100.00\% (positive class: Resiko) } \\
& true Normal & true Resiko & class precision \\
\hline pred. Normal & 31 & 0 & $100.00 \%$ \\
\hline pred. Resiko & 4 & 20 & $83.33 \%$ \\
\hline class recall & $88.57 \%$ & $100.00 \%$ & \\
\hline
\end{tabular}

Gambar 8. Nilai class recall

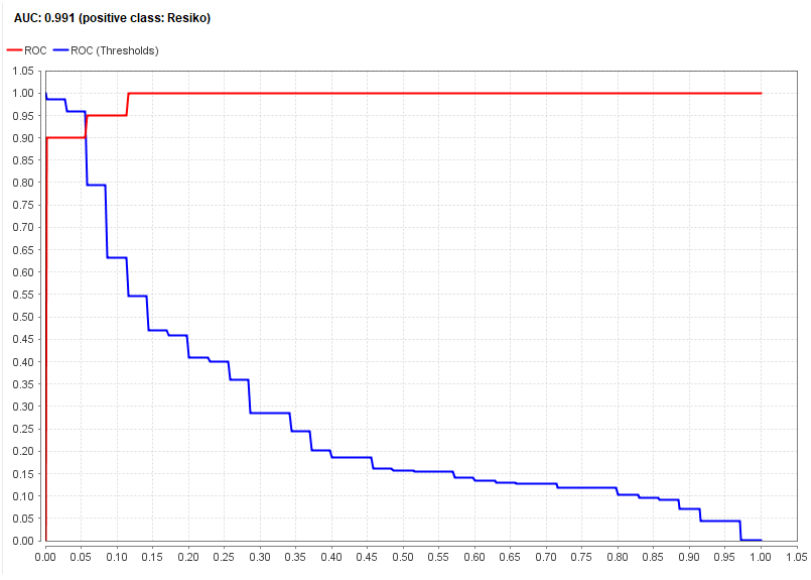

Gambar 9. Nilai AUC

Nilai Auc (Area Under Curve) adalah sebesar 0.991. Berdasarkan grafik tersebut maka penggunaan metode dalam penelitian ini termasuk kategori Excellent Classification. 


\section{PENUTUP}

\section{Kesimpulan}

Berdasarkan hasil penelitian yang telah dibuat dari tahap analisa, perancangan, implementasi dan setelah melakukan pengujian sistem terhadap penelitian ini maka terdapat beberapa hal yang dapat disimpulkan, yaitu sebagai berikut:

1. Sistem dapat digunakan untuk memprediksi kondisi kelahiran bayi, lahir secara normal atau beresiko menggunakan metode klasifikasi naive bayes

2. Dengan menggunakan data hasil pemeriksaan dokter sistem prediksi yang dibuat telah dapat menentukan rata-rata kelahiran normal ataupun kelahiran secara beresiko disetiap bulannya.

\section{Saran}

Pada penelitian ini masih banyak kekurangan yang perlu diperbaiki. Sehingga memerlukan penyempurnaan yang dapat membangun agar penelitian ini memiliki nilai yang lebih bermanfaat di kemudian hari. Maka penulis memberikan beberapa saran yaitu:

1. Diharapkan pada pengembangan selanjutnya digunakan metode lain untuk diketahui untuk metode mana yang lebih efektif terhadap kasus ini.

2. Diharapkan pada pengembangan selanjutnya digunakan bahasa pemrograman yang lain.

\section{DAFTAR PUSTAKA}

1. Kusrini dan Emha Taufiq Luthfi. 2009. Algoritma Data Mining. Penerbit Andi. Yogyakarta.

2. Pramudiono, I. 2006. Apa itu Data Mining? Dalam http://datamining.japati.net/ cgibin/indodm.cgi. Diakses tanggal 26 November 2015.

3. Han J dan Kamber M. 2006. Data mining Concepts and Techniques 2nd Edition. The Morgan Kaufmann Publisher, San Fransisco.

4. H. Wiknjosastro, 2000. "Ilmu Kebidanan", Jakarta:PT. Bina Pustaka Sarwono Prawirohardjo,
5. Tim Kajian AK. 2005."Kajian kematian ibu dan anakdi Indonesia," Badan Penelitian danPengembangan Kesehatan. Jakarta: Depkes RI,.

6. B. Max, 2007, Principles of Data Mining, Undergraduate Topics in Computer Science ISSN: 1863-7310, London: Springer,

7. Anastasia Hasni G. dan Setiadi Tedy, "Penerapan data mining untuk mengetahui factor-faktor yang mempengaruhi kelahiran bayi menggunakan association rules", Jurnal Sarjana Teknik Informatika e-ISSN: 23385197 Volume 2 Nomor 3, Oktober 2014.

8. Muzakir Ari dan Wulandari Rika Anisa, "Model Data Mining sebagai Prediksi Penyakit Hipertensi Kehamilan dengan Teknik Decision Tree", Scientific Journal of Informatics, Vol. 3, No. 1, Mei 2016.

9. Amalia Hilda dan Evicienna, "Komparasi Metode Data Mining Untuk Penentuan Proses Persalinan Ibu Melahirkan", Jurnal Sistem Informasi (Journal of Information System), Volume 13, Issue 2, October 2017

10. F. Gorunescu, "Data mining Concept and Technique", Verlag Berlin Heidelberg: Springer, 2011.

11. Indraswari, N. R., \& Kurniawan, Y. I. (2018). Aplikasi Prediksi Usia Kelahiran Dengan Metode Naïve Bayes. Simetris: Jurnal Teknik Mesin, Elektro dan Ilmu Komputer, 9(1), 129-138.

12. Kurniawan, Y. I. (2018). Perbandingan Algoritma Naive Bayes dan C. 45 dalam Klasifikasi Data Mining. Jurnal TeknologiInformasi dan Ilmu Komputer, 5(4), 455-464.

13. Indahsari Desy Kartika, Kurniawan Yogiek Indra, 2019, Aplikasi Prediksi Usia Kelahiran Dengan Metode K-Nearest Neighbor, Jurnal Kebidanan, Vol. XI, No. 01, Juni 2019.

14. Jefi, 2019, Prediksi Bayi Lahir Secara Prematur Dengan Menggunakan Metode C.45 Berbasis Particle Swarm Optimization 
Pada Klinik Umi, Indonesian Journal on Networking and Security - Volume 8 No 2 2019.

15. Alfironi Burhan, 2013, Implementasi Data Mining Dengan Naive Bayes Classifier Untuk Mendukung Strategi Pemasaran Di bagian Humas Stmik Amikom Yogyakarta, Yogyakarta. 